園学雑. (J. Japan. Soc. Hort. Sci.) 68(3) : 614-621. 1999.

\title{
プリムラ・オブコニカのプリミン保有品種とフリー品種における 毛じの形態学的特性
}

\author{
樋口幸男 ${ }^{1} \cdot$ 北島章好 $^{2} \cdot$ 荻原 勲 $^{2} \cdot$ 箱田直紀 ${ }^{2} \cdot$ 志村 勲 $^{2}$ \\ ${ }^{1}$ 恵泉女学園大学人文学部 $206-0032$ 東京都多摩市南野 2-10-1 \\ 2 東京農工大学農学部 183-8509 東京都府中市幸町 3-5-8
}

\begin{abstract}
Morphological Characteristics of Trichomes of Primin-Secreting and Primin-Free Cultivars in Primula obconica
Yukio Higuchi $^{1}$, Akiyoshi Kitajima ${ }^{2}$, Isao Ogiwara ${ }^{2}$, Naotoshi Hakoda ${ }^{2}$ and Isao Shimura ${ }^{2}$

${ }^{1}$ Faculty of Humanity, Keisen University, 2-10-1, Minamino, Tama, Tokyo 206-0032

${ }^{2}$ Faculty of Agriculture, Tokyo University of Agriculture and Technology, 3-5-8, Saiwaicho, Fuchu, Tokyo 183-8509
\end{abstract}

\begin{abstract}
Summary
A comparison of the trichome types was made by the Craven test and microscopic observation between primin - secreting and primin-free cultivars of Primula obconica.

1. All cultivars were classified into two groups according to the lengths of trichomes. Group one had trichomes (Fig.1, A D) whose lengths were $150 \mu \mathrm{m}$ or less, whereas group two was represented by those with trichomes exceeding $1 \mathrm{~mm}$ (Fig.1, E). Moreover, the trichomes of group one was further classified into four types from the characteristics of the tips, e.g., A : red tip; B : colorless tip ; C : yellow tip and D :tip with crystallized substance (Fig.1, A,B,C and D, respectively).

2. The trichomes of B, C, and D types were observed both on the primin-secreting and free cultivars but those of A type were observed only on the primin-secreting cultivars. By the Craven test, only the trichome of A type secreted primin at its apex.

3. The distribution density of A type trichome (primin-secreting) was higher on the basal part of the midrib in leaves and on the calyx and peduncle in flower clusters, than in other parts of leaves and flower clusters.

Thus, it should be possible to select primin-free plants by avoiding the plants with red tipped trichomes on midrib of young leaves, calyx and peduncle of flower clusters.
\end{abstract}

Key Words: Primula obconica, primin, forms of trichomes, Craven test.

\section{緒言}

プリムラ・オブコニカ (Primula obconica Hance)は花 色が豊富で, 耐陰性が高く, 鑑賞期間が長いことから, 我 が国では年末から早春までの鉢花として生産されている (肥土，1994). しかし，植物体が皮膚に接触するとアレル ギー性皮膚炎を引き起こす場合があり，このことが需要 増加の阻害要因となっている.

このアレルギー性皮膚炎を引き起こす物質は Bloch ・ Karrer (1927)によってプリミンと命名され， Schildknecht ら (1967)により 2-methoxy-6-pentyl-benzoquinone 上同定されている．また，プリミンの生合成経路 は Horper・Marner (1996)によって報告されている.

1998 年 2 月 6 日 受付. 1998年 8 月 5 日 受理.

本研究の一部は園芸学会平成 9 年度秋季大会において発表した。
プリミンの分泌は温度によって影響され (Klein・Tröthandl, 1929), 高温長日条件下で増加する (Horn, 1990). また, Storck (1938) はプリミン分泌量に品種間差異があ ることを報告している。さらに，Heyting・Toxopeus (1989)はキノン検定試薬 (Craven, 1931)による Craven test (Heyting • Toxopeus, 1987)を用いて, プリムラ・オ ブコニカの交雑実生を検定し，プリミンの遺伝特性を報 告している.

近年, プリミンを保有していない品種 (以下, フリー品 種という)が育成されているが,これら品種の毛じの形態 は明らかにされていない，プリミンは毛じから分泌され るので, フリー品種と保有品種の毛じの形態を比較すれ ば，その形態的差異からもプリミンの有無を検定するこ とが可能になると考えられる.

そこで, 本実験では, 毛じの形態および毛じからのプリ ミンの分泌状況をプリミン保有品種およびフリー品種を 
Table 1. Presence and absence of primin based on Craven test of eighteen cultivars in Primula obconica.

\begin{tabular}{|c|c|c|c|}
\hline \multirow{2}{*}{ Cultivar } & \multirow{2}{*}{$\begin{array}{l}\text { Number of the } \\
\text { observed plants }\end{array}$} & \multicolumn{2}{|c|}{ Response of Craven test } \\
\hline & & + & - \\
\hline \multicolumn{4}{|l|}{ Crystal series } \\
\hline Crystal Scarlet & 36 & 36 & 0 \\
\hline Crystal Apricot & 36 & 36 & 0 \\
\hline Crystal Carmine & 36 & 36 & 0 \\
\hline Crystal Rose & 36 & 36 & 0 \\
\hline Crystal Pink & 36 & 36 & 0 \\
\hline Crystal Blue & 36 & 36 & 0 \\
\hline Crystal Lavender & 36 & 36 & 0 \\
\hline Crystal Red and white & 36 & 36 & 0 \\
\hline \multicolumn{4}{|l|}{ Prino series } \\
\hline Prino Orange & 54 & 0 & 54 \\
\hline Prino Rose & 54 & 0 & 54 \\
\hline Prino Blue & 54 & 0 & 54 \\
\hline Prino Light blue & 54 & 0 & 54 \\
\hline Prino White & 54 & 0 & 54 \\
\hline \multicolumn{4}{|l|}{ Libre series } \\
\hline Libre Light salmon & 54 & 0 & 54 \\
\hline Libre Magenta & 54 & 0 & 54 \\
\hline Libre Pink & 54 & 0 & 54 \\
\hline Libre Blue & 54 & 0 & 54 \\
\hline Libre White & 54 & 0 & 54 \\
\hline
\end{tabular}

用いて比較し，毛じの形態からプリミンの有無を明らか にする方法を確立しようとした。

\section{材料および方法}

実験 1. Craven testによるプリミンの有無の判定 供試材料には‘クリスタル・スカーレット’ほか 18 品 種 (第 1 表)を用いた。'クリスタル’シリーズの各品種は 36 個体，“プリノー’シリーズおよび・リブレ’シリーズ の各品種は 54 個体を供試した。供試品種は 1996年 6 月 25 日には種し， $80 \%$ 遮光条件のパイプハウスで㕕苗を行 い，その成葉を供試して Craven testを 8 月 25 日に行っ た. Heyting・Toxopeus (1987)によって確立された Craven test は $96 \%$ エタノールと $25 \%$ アンモニア水溶液を 3 対 7 の比率で混和した液を滴下した綿棒で葉および葉柄 の裏側を拭い，次いで，その綿棒にシアノ酢酸エチルを 少量滴下して，その部位が青色を呈した場合にプリミン を保有しているものと判定する方法である.

実験 2. プリミン保有品種およびフリー品種にお ける毛じの外部形態の比較

供試材料には, Craven testに反応しプリミンを保有し ていると判断された'クリスタル・アプリコット’, ‘クリ スタル・カーマイン’および'クリスタル・ブルー’と, Craven testの反応がなくプリミンを保有していないと判断さ れた'プリノー・オレンジ’, ‘プリノー・ライトブルー’お

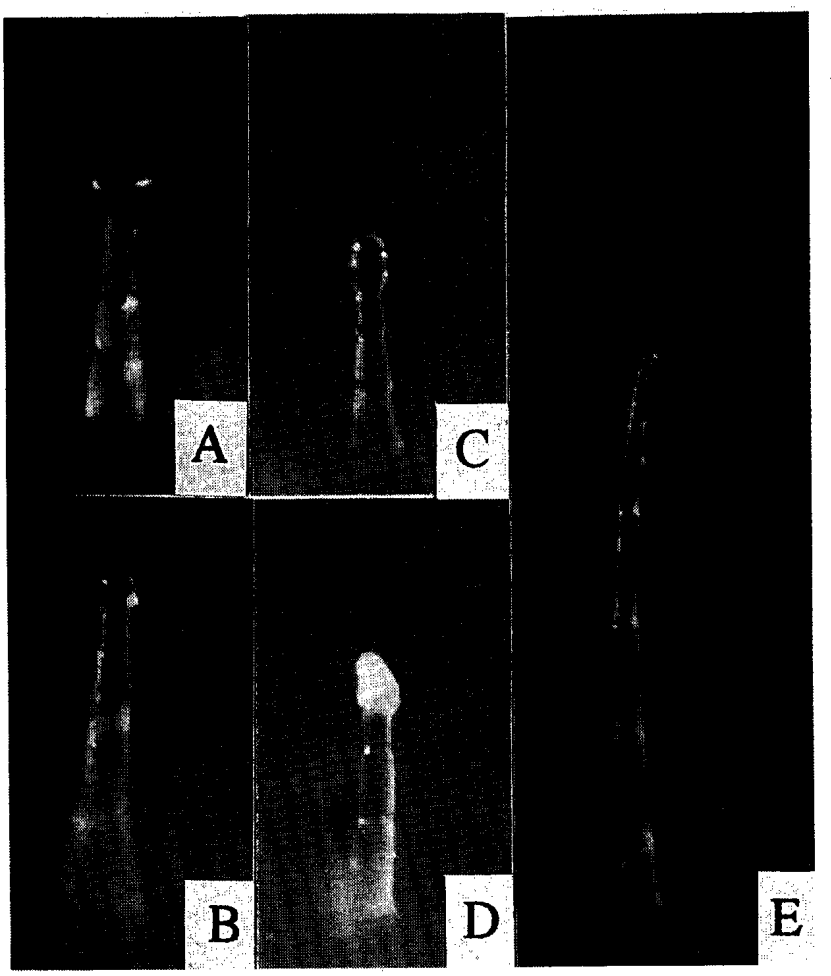

Fig. 1. Photographs of five types of trichomes (type A to E) observed under light microscope in Primula obconica.

A. red tipped trichome. $(\times 200)$ B. colorless tipped trichome. $(\times 200)$ C. yellow tipped trichome. $(\times 200)$ D. trichome with crystallized substance. $(\times 200)$ E. long trichome, more than 1 mm. $(\times 40)$ 
Table 2. Distribution of various types of trichomes on leaves and flower clusters of 'Crystal Apricot' and 'Prino Orange' cultivars in Primula obconica.

\begin{tabular}{|c|c|c|c|c|c|c|c|c|c|c|c|}
\hline \multicolumn{2}{|c|}{ Observed part } & \multicolumn{5}{|c|}{ Cystal Apricot $^{2}$} & \multicolumn{5}{|c|}{ Prino Orange $^{\mathrm{z}}$} \\
\hline Organ & Part & A & B & $\mathrm{C}$ & $\mathrm{D}$ & $\mathrm{E}$ & A & $\mathrm{B}$ & $\mathrm{C}$ & $\mathrm{D}$ & $\mathrm{E}$ \\
\hline Petiole & & $t^{\mathrm{y}}$ & + & + & + & + & - & + & + & + & + \\
\hline \multirow{3}{*}{ Leaf blade } & Midrib & + & + & - & + & + & - & + & - & + & + \\
\hline & Lateral vein & + & + & - & + & + & - & + & - & + & + \\
\hline & Surface among veins & + & + & - & + & + & - & + & - & + & + \\
\hline Flower stalk & - & + & + & + & + & + & - & + & + & + & + \\
\hline Peduncle & - & + & + & - & + & + & - & + & + & + & + \\
\hline Calyx & Abaxial surface & + & + & - & + & + & - & + & + & + & + \\
\hline Calyx & Adaxial surface & + & + & - & + & - & - & + & + & + & - \\
\hline Floral tube & Abaxial surface & + & + & - & + & - & - & + & + & + & - \\
\hline Floral tube & Adaxial surface & - & + & + & + & - & - & + & + & + & - \\
\hline Petal & Abaxial surface & + & + & - & + & - & - & + & - & + & - \\
\hline Petal & Adaxial surface & + & + & - & + & - & - & + & - & + & - \\
\hline
\end{tabular}

${ }^{2}$ Type of trichome. A: red tipped trichome; B: colorless tipped trichome; C: yellow tipped trichome; D: trichome with crystallized substance and $\mathrm{E}$ : long trichome.

${ }^{\mathrm{y}}+$ and - indicate presence and absence of each type of trichomes, respectively.

よび・リブレ・ライトサーモン’を用いた。供試材料は実 験 1 と同様に育苗し, 翌年の 5 月に開花した株の成葉を用 いて，毛じの外部形態を実体顕微鏡下で観察した。

実験 3.プリミン保有品種およびフリー品種にお ける毛じの分布および発生量とプリミン の分泌状況

供試材料には“クリスタル・アプリコット’および'プ リノー・オレンジ'を用いた。供試材料は実験 1 と同様に 育苗し，翌年の5月に開花した株を用いた。毛じの分布お よび毛じ量の調査には各品種 3 個体を用いた. 毛じは長 さや色に着目して形態区分し，毛じの分布は部位別に各 形態の有無を調査した，毛じ量の調査には各個体当たり 幼葉 4枚と花房 4本を用いた. 毛じ量は両品種の葉および 花房の各部位 (第 3表，第 4表)における $1 \mathrm{~mm}^{2}$ 当たりの 全毛じを数え，毛じ数に応じて指標で示した．すなわち， 毛じ量は $1 \mathrm{~mm}^{2}$ 当たりの毛じ数に応じて 5段階 $(0: 0$ 本, $1: 1 \sim 9$ 本, $2: 10 \sim 30$ 本, $3: 31 \sim 50$ 本, $4: 51$ 本以上 )に 区別して評価した。

また，プリミン分泌毛じ率はプリミン保有品種である 'クリスタル・アプリコット’のみ調査した，調査には 3個 体を用い, 各個体当たり幼葉と成葉各 4枚と花房 4本とを 用いた. プリミン分泌毛じ率 (プリミン分泌毛じ数/全毛 じ数× 100) は 5 段階 $(0: 0 \%, 1: 10 \%$ 未満, $2: 10 \sim 40$ $\%, 3: 40 \sim 70 \%, 4: 70 \%$ 以上)に区分して評価し, 平均 值で示した。

\section{結果}

実験 1. Craven testによるプリミンの有無の判定 'クリスタル’シリーズの各品種は供試した全個体が
Craven test で青色を呈したが，“プリノー’シリーズおよ び'リブレ’シリーズは各品種とも青色を呈した個体が認 められなかった(第 1 表). Craven testの結果から'クリ スタル’シリーズの 8 品種はプリミン保有品種であり, ‘プ リノー’シリーズの 5 品種および・リブレ’シリーズの 5 品 種はフリー品種と判断された.

実験 2. プリミン保有品種およびフリー品種にお ける毛じの外部形態の比較

プリミン保有品種とフリー品種の葉の毛じを観察した ところ，2 5節を有し，長さが $150 \mu \mathrm{m}$ 以下の短い毛じ ( 第 1 図 $\mathrm{A} \sim \mathrm{D}$ ) と, 長さ $1 \mathrm{~mm}$ 以上の長い毛じ (第 1 図 $\mathrm{E}, \mathrm{E}$ タイプ)が観察された. また, 短い毛じは先端部の形態に より 4つに区分できた. すなわち, 先端部が球状で赤褐色 の分泌物を有する毛じ (第 1 図 A, A夕イプ), 先端部が 半球状でほぼ無色の毛じ (第 1 図 $\mathrm{B}, \mathrm{B}$ タイプ), 先端部 が半球状で黄褐色の分泌物を有する毛じ (第 1 図 C, C夕 イプ), および先端部に白色の結晶状の物質が付着した毛 じ(第1図 D, D タイプ)が観察された. そして, 赤褐色

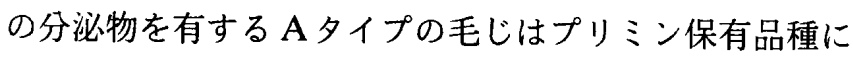
のみ観察された．この赤褐色の分泌物をガラス細管で集 めCraven testを行ったところ青色を呈したため, 赤褐色 の分泌物はプリミンと同定された. 従って，この赤褐色 の分泌物を先端部に有する $\mathrm{A}$ タイプの毛じの有無により, プリミン保有品種とフリー品種の区別が可能であった. なお，Eタイプの毛じの先端部は，ほとんど分泌物が認め られなかったが，まれに黄褐色の分泌物が認められた。し かし，Eタイプの毛じの先端部に赤褐色の分泌物は認め られなかった。 
Table 3. Trichome index on leaves of 'Crystal Apricot' and 'Prino Orange' cultivars in Primula obconica.

\begin{tabular}{|c|c|c|c|c|c|}
\hline \multirow[b]{2}{*}{ Organ } & \multirow{2}{*}{$\begin{array}{l}\text { Observed part } \\
\begin{array}{c}\text { Adaxial surface or } \\
\text { abaxial surface }\end{array}\end{array}$} & \multirow[b]{2}{*}{ Part } & \multicolumn{2}{|c|}{ Trichome index ${ }^{2}$} & \multirow[b]{2}{*}{ Significance $^{y}$} \\
\hline & & & Crystal Apricot & Prino Orange & \\
\hline \multirow{4}{*}{ Petiole } & Abaxial surface & Stem side & 2.1 & 2.3 & NS \\
\hline & Abaxial surface & Blade side & 2.3 & 2.4 & NS \\
\hline & Adaxial surface & Stem side & 2.1 & 2.3 & NS \\
\hline & Adaxial surface & Blade side & 2.3 & 2.5 & NS \\
\hline \multirow{7}{*}{$\begin{array}{l}\text { Leaf blade } \\
\text { (basal part) }\end{array}$} & Abaxial surface & Midrib & 2.5 & 2.6 & NS \\
\hline & Abaxial surface & Lateral vein & 2.5 & 2.8 & NS \\
\hline & Abaxial surface & Surface among veins & 1.3 & 0.5 & $* *$ \\
\hline & Adaxial surface & Midrib & 2.0 & 2.1 & NS \\
\hline & Adaxial surface & Lateral vein & 1.3 & 1.5 & NS \\
\hline & Adaxial surface & Surface among veins & 1.3 & 1.1 & NS \\
\hline & & Leaf margin & 3.0 & 3.0 & NS \\
\hline \multirow{7}{*}{$\begin{array}{l}\text { Leaf blade } \\
\text { (central part) }\end{array}$} & Abaxial surface & Midrib & 2.5 & 2.5 & NS \\
\hline & Abaxial surface & Lateral vein & 2.5 & 2.7 & NS \\
\hline & Abaxial surface & Surface among veins & 1.3 & 0.4 & $* *$ \\
\hline & Adaxial surface & Midrib & 1.5 & 2.0 & $* *$ \\
\hline & Adaxial surface & Lateral vein & 1.0 & 1.4 & $* *$ \\
\hline & Adaxial surface & Surface among veins & 1.2 & 1.0 & NS \\
\hline & & Leaf margin & 3.0 & 3.0 & NS \\
\hline \multirow{7}{*}{$\begin{array}{l}\text { Leaf blade } \\
\text { (distal part) }\end{array}$} & Abaxial surface & Midrib & 2.6 & 2.7 & NS \\
\hline & Abaxial surface & Lateral vein & 2.5 & 2.5 & NS \\
\hline & Abaxial surface & Surface among veins & 1.3 & 0.4 & $* *$ \\
\hline & Adaxial surface & Midrib & 1.0 & 1.4 & $* *$ \\
\hline & Adaxial surface & Lateral vein & 1.0 & 1.1 & NS \\
\hline & Adaxial surface & Surface among veins & 1.3 & 1.0 & $* *$ \\
\hline & & Leaf margin & 3.0 & 3.0 & NS \\
\hline LSD 5\% & & & 0.3 & 0.3 & \\
\hline LSD $1 \%$ & & & 0.4 & 0.4 & \\
\hline
\end{tabular}

\footnotetext{
${ }^{z}$ Trichome index were investigated and presented by the following index.

Index: trichomes number $/ \mathrm{mm}^{2} ; 0: 0 ; 1: 1 \sim 9 ; 2: 10 \sim 30 ; 3: 31 \sim 50$ and $4: 51<$.

Values represented the average of index $(n=12)$.

$\mathrm{y} *,{ }^{* *}$ and NS indicate significance at $\mathrm{p}=0.05,0.01$ and no significance, respectively.
}

実験 3. プリミン保有品種およびフリー品種にお ける毛じの分布および発生量とプリミン の分泌状況

実験 2で観察された A，B，C，DおよびEタイプの毛じ がそれぞれ葉や花房のどの部位に発生しているかを明ら かにするため, プリミン保有品種“クリスタル・アプリコ ット’およびフリー品種 ‘プリノー・オレンジ’の葉およ び花房の各部位における各形態の毛じの有無を調査した (第2表).Aタイプの毛じは‘クリスタル・アプリコット’ では花筒部の内側を除くすべての部位に分布していたが, ‘プリー・オレンジ’には認められなかった。Bおよび Dタイプの毛じは両品種の各部位に認められた. Cタイ プの毛じは‘クリスタル・アプリコット’では葉柄, 花茎
および花筒部内側に分布していたが, ‘プリノー・オレン ジでは花柄やがくなどにも分布していた．Eタイプの毛 じは両品種とも葉柄，葉身，花柄およびがく基部に分布 していたが，花筒部や花弁では認められなかった。

次に“クリスタル・アプリコット’および・プリノ一・ オレンジ’の葉および花房の各部位における毛じ量を比較 した (第 3表, 第 4表). 毛じは両品種ともすべての器官に 分布していたが，毛じ量は部位により異なったすすなわ ち, 毛じ量は両品種とも葉の葉縁, 裹面の主脈と側脈, 花 柄とがく基部の外側などで多く, 表面の主脈と側脈, 葉 脈間，花弁などで少なかった。 また，毛じ量を品種間で 比較すると，裏面の葉脈間，花弁，蕾の内側などでは‘ク リスタル・アプリコット’が・プリノー・オレンジ’より 
Table 4. Trichome index on flower cluster of 'Crystal Apricot' and 'Prino Orange' cultivars in Primula obconica.

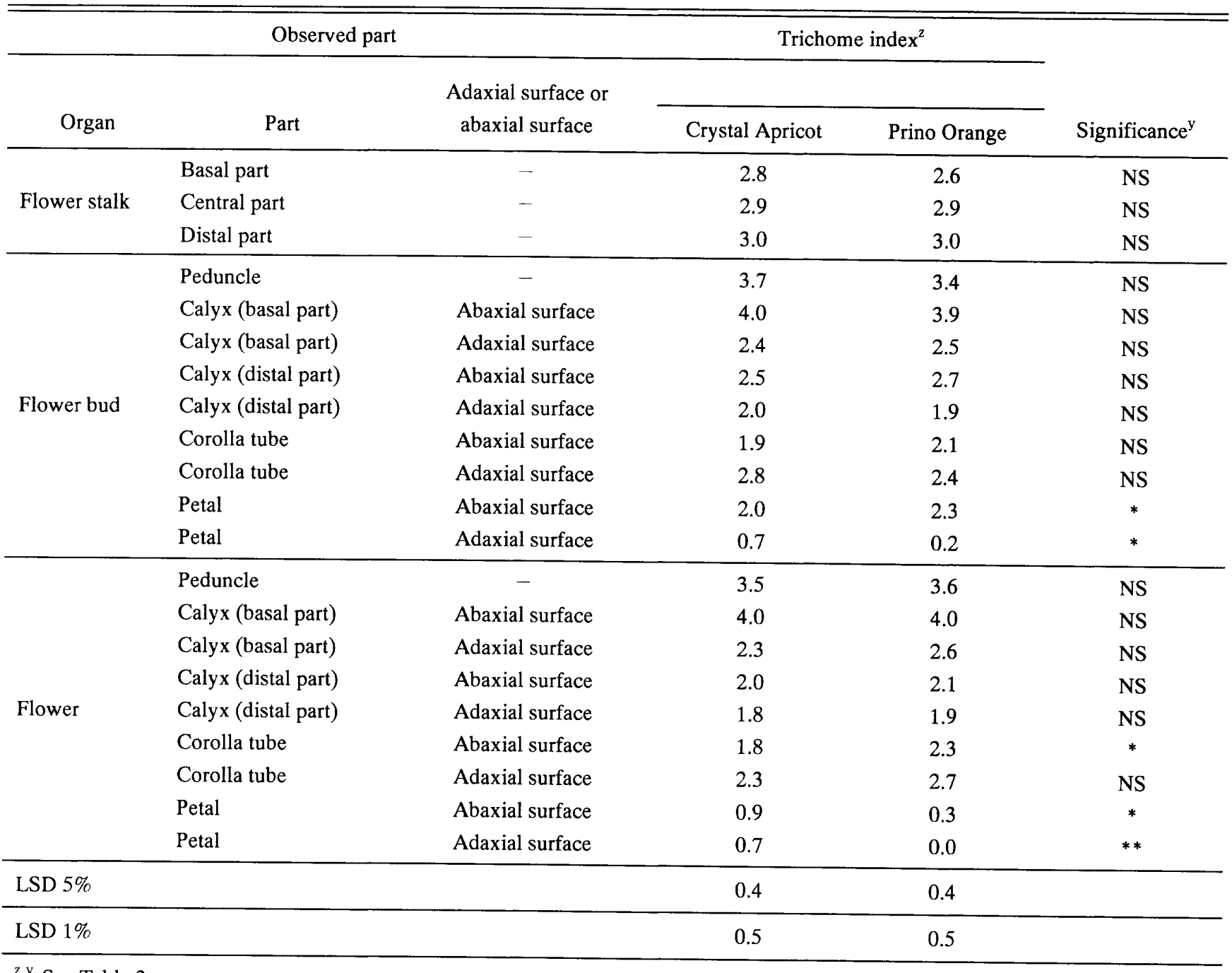

${ }^{z, y}$ See Table 3.

も多く, 蕾の花弁部外側は ‘プリノー・オレンジ’が'ク リスタル・アプリコット’よりも多かった．しかし，その 他の部位では品種間に相違は認められなかった。

次に, プリミン保有品種の'クリスタル・アプリコット’ の各部位におけるプリミン分泌毛じ率をみると(第 5 表, 第 6 表 $),$ プリミン分泌毛じ率は部位間で相違が認められ た.すなわち, 葉では幼葉および成葉の裹面の主脈基部 や葉柄上部裏側などが高く, 葉表面の側脈先端部之葉縁 部などで低かった．幼葉と成葉を比較すると葉柄の上部, 葉の表面の主脈などの多くの部位で，幼葉のプリミン分 泌毛じ率は成葉のそれに比べて高かった，花房ではがく および花柄などが高く, 花弁の内側, 花茎基部, 花筒部 内側などで低かった．また，蕾と開花後の花を比較する と, がく基部，花筒部外側および花弁内側で開花後の花 が高く，その他の部位では差異は認められなかった。

\section{考察}

本実験ではプリムラ・オブコニカにおける毛じの形態 をプリミン保有品種とフリー品種を用いて比較検討した. その結果, 短い毛じ(第 1 図 A D ) と, 長い毛じ (第 1 図
E, Eタイプ)が観察され，さらに短い毛じは4つの夕イ プ $(\mathrm{A}, \mathrm{B}, \mathrm{C} ， \mathrm{D}) に$ に分された，そこで，プリミン保有品 種とフリ一品種を用いて, 各形態の毛じの各器官におけ る発生の有無を調査したところ，Bおよび Dタイプの毛 じの発生部位には品種間で相違がなかったが, A と C 夕 イプの毛じの発生部位には品種間で差が認められた。特 に注目すべきことは, プリミン保有品種にはA夕イプの 毛じが観察されたが, プリミンフリ一品種にはそれが認 められなかったことである.さらに，A夕イプの毛じに 認められた赤褐色の分泌物だけが Craven testに反応し, プリミンが含まれていることがわかった，従って，先端 部に赤褐色で球状の分泌物を有する A タイプの毛じの有 無により，プリミン分泌の有無を知ることが可能である と考えられた．また，Cタイプの毛じは両品種に発生し ていたが, 発生部位は異なっていた。しかし,フリー品 種にはAタイプの毛じがなく、Cタイプの毛じが発生し ていたことと, 保有品種において A夕イプとCタイプの 中間的な形態の毛じが認められなかったことから，C夕 イプの毛じからA夕イプの毛じへ変化することはないも のと考えられたが，この点に関しては今後検討する必要 
園学雑. (J. Japan. Soc. Hort. Sci.) 68 (3) : 614-621. 1999.

Table 5. Rate of trichomes secreting primin on leaves of 'Crystal Apricot' cultivars in Primula obconica.

\begin{tabular}{|c|c|c|c|c|c|}
\hline \multirow[b]{2}{*}{ Organ } & \multicolumn{2}{|l|}{ Observed part } & \multicolumn{2}{|c|}{ Index of trichomes secreting primin ${ }^{z}$} & \multirow[b]{2}{*}{ Significance $^{\mathrm{y}}$} \\
\hline & $\begin{array}{l}\text { Adaxial surface or } \\
\text { abaxial surface }\end{array}$ & Part & Young leaf & Mature leaf & \\
\hline \multirow{4}{*}{ Petiole } & Abaxial surface & Stem side & 1.4 & 1.0 & NS \\
\hline & Abaxial surface & Blade side & 1.7 & 1.3 & NS \\
\hline & Adaxial surface & Stem side & 1.4 & 0.9 & $*$ \\
\hline & Adaxial surface & Blade side & 1.9 & 1.0 & $* *$ \\
\hline \multirow{7}{*}{$\begin{array}{l}\text { Leaf blade } \\
\text { (basal part) }\end{array}$} & Abaxial surface & Midrib & 2.2 & 1.6 & $* *$ \\
\hline & Abaxial surface & Lateral vein & 1.4 & 0.9 & $* *$ \\
\hline & Abaxial surface & Surface among veins & 0.9 & 0.3 & $* *$ \\
\hline & Adaxial surface & Midrib & 2.3 & 1.0 & $* *$ \\
\hline & Adaxial surface & Lateral vein & 1.4 & 0.4 & $* *$ \\
\hline & Adaxial surface & Surface among veins & 0.8 & 0.3 & $* *$ \\
\hline & & Leaf margin & 0.6 & 0.0 & $* *$ \\
\hline \multirow{7}{*}{$\begin{array}{l}\text { Leaf blade } \\
\text { (central part) }\end{array}$} & Abaxial surface & Midrib & 1.8 & 1.4 & NS \\
\hline & Abaxial surface & Lateral vein & 1.3 & 0.8 & $*$ \\
\hline & Abaxial surface & Surface among veins & 1.0 & 0.2 & $* *$ \\
\hline & Adaxial surface & Midrib & 1.7 & 0.8 & $* *$ \\
\hline & Adaxial surface & Lateral vein & 0.9 & 0.2 & $* *$ \\
\hline & Adaxial surface & Surface among veins & 0.9 & 0.4 & $* *$ \\
\hline & & Leaf margin & 0.3 & 0.3 & NS \\
\hline \multirow{7}{*}{$\begin{array}{l}\text { Leaf blade } \\
\text { (apical part) }\end{array}$} & Abaxial surface & Midrib & 1.1 & 1.0 & NS \\
\hline & Abaxial surface & Lateral vein & 1.0 & 0.9 & NS \\
\hline & Abaxial surface & Surface among veins & 1.1 & 0.3 & $* *$ \\
\hline & Adaxial surface & Midrib & 0.4 & 0.4 & NS \\
\hline & Adaxial surface & Lateral vein & 0.4 & 0.1 & $* *$ \\
\hline & Adaxial surface & Surface among veins & 0.9 & 0.3 & $* *$ \\
\hline & & Leaf margin & 0.3 & 0.3 & NS \\
\hline LSD 5\% & & & 0.6 & 0.5 & \\
\hline LSD $1 \%$ & & & 0.6 & 0.7 & \\
\hline
\end{tabular}

${ }^{2}$ Index of trichomes secreting primin was calculated from the following equation, (No. of trichomes secreting primin / No. of all trichomes) $\times 100 \%$, and then these results were presented by the following index.

Index: trichomes secreting primin (\%); $0: 0 \% ; 1:>10 \% ; 2: 10 \sim 40 \% ; 3: 40 \sim 70 \%$ and $4: 70 \%<$.

Values represented the average of index $(n=12)$.

$\mathrm{y} *{ }^{* *}$ and NS indicate significance at $\mathrm{p}=0.05,0.01$ and no significance, respectively.

があると思われた。 さらに，毛じの先端部には白色で結 晶状の物質が存在する Dタイプの毛じか観察された (第 1 図 D)が, Bini Maleci ら (1992)はこの結晶状の物質を水 道水に含まれる炭酸カルシウムと推察しており，プリミ ンの分泌とは直接の関係がないものと考えられた。

次に, プリミン保有品種およびフリー品種の各器官に おける毛じの発生量の相違を検討した，その結果，毛じ の発生量は葉裹面の葉脈間や花弁などの部位で相違が認 められたが, 毛じ量の指数が 1 以上異なる部位はなかっ た. そこで，プリミン保有品種にのみに認められる A夕 イプの毛じがどこの部位で多く発生しているかを検討し た(第 5 表, 第 6 表). その結果, Aタイプ(第 1 図A)の毛 じは, 部位により発生量に差異が認められ, 葉では裹面
の主脈基部で, 花房では花柄およびがく基部で多かった. このことから, プリミンの有無を判断するには, 葉裏面 の主脈基部あるいは花房のがくや花柄の毛じを観察する ことが望ましいと考えられた．また，葉では成葉より幼 葉においてプリミンの分泌が多かった(第 5 表). このこ とは成葉におけるプリミン分泌能力が幼葉よりも低下し ているか, あるいは葉同士の接触によってプリミンを含 む分泌物が脱落したことによるものと思われた.なお，こ れらの結果は開花株を用いたものであるが，プリミンの 遺伝の解明やプリミンフリーの育種に応用するには幼苗 期にプリミン検定を行うことが必要と思われる. 今後は 幼苗期における葉齢とプリミン分泌との関係を検討する 必要がある。 
Table 6. Rate of trichomes secreting primin on flower cluster of 'Crystal Apricot' cultivars in Primula obconica.

\begin{tabular}{|c|c|c|c|}
\hline \multicolumn{3}{|c|}{ Observed part } & \multirow[b]{2}{*}{$\begin{array}{l}\text { Index of trichomes } \\
\text { secreting primin }^{2}\end{array}$} \\
\hline Organ & Part & $\begin{array}{l}\text { Adaxial surface or } \\
\text { abaxial surface }\end{array}$ & \\
\hline \multirow{3}{*}{ Flower stalk } & Basal part & - & 0.8 \\
\hline & Central part & - & 0.9 \\
\hline & Distal part & - & 2.1 \\
\hline \multirow{9}{*}{ Flower bud } & Peduncle & - & 2.3 \\
\hline & Calyx (basal part) & Abaxial surface & 2.5 \\
\hline & Calyx (basal part) & Adaxial surface & 1.6 \\
\hline & Calyx (distal part) & Abaxial surface & 2.4 \\
\hline & Calyx (distal part) & Adaxial surface & 2.5 \\
\hline & Corolla tube & Abaxial surface & 2.4 \\
\hline & Corolla tube & Adaxial surface & 0.0 \\
\hline & Petal & Abaxial surface & 2.1 \\
\hline & Petal & Adaxial surface & 0.0 \\
\hline \multirow{9}{*}{ Flower } & Peduncle & - & 2.8 \\
\hline & Calyx (basal part) & Abaxial surface & 3.1 \\
\hline & Calyx (basal part) & Adaxial surface & 3.5 \\
\hline & Calyx (distal part) & Abaxial surface & 2.7 \\
\hline & Calyx (distal part) & Adaxial surface & 3.0 \\
\hline & Corolla tube & Abaxial surface & 3.0 \\
\hline & Corolla tube & Adaxial surface & 0.0 \\
\hline & Petal & Abaxial surface & 2.0 \\
\hline & Petal & Adaxial surface & 0.8 \\
\hline LSD $5 \%$ & & & 0.6 \\
\hline LSD $1 \%$ & & & 0.8 \\
\hline
\end{tabular}

${ }^{z}$ See Table 5 .

以上のことから，プリミン保有品種とフリー品種では, A夕イプの毛じの有無が異なり, 花房のがく, 花柄ある いは幼葉の主脈基部の毛じ先端部に赤褐色の分泌物が有 るか，否かを観察することにより，容易にプリミンの有 無を判定できることがわかった．

\section{摘 要}

プリムラ・オブコニカのプリミン保有品種およびフリー 品種における毛じの形態学的特性を実体顕微鏡を用いて 比較検討した.

1. プリムラ・オブコニカの毛じは, 毛じの長さから 150 $\mu \mathrm{m}$ 以下の短い毛じ (第 1 図 $\mathrm{A} \sim \mathrm{D}$ ) と, $1 \mathrm{~mm}$ 以上の長い 毛じ(第1図 E，Eタイプ)に分けられた．短い毛じは4つ のタイプに区分され，Aタイプ: 先端部が球状で赤褐色 の分泌物を有する毛じ(第1図 A), B タイプ：先端部が 半球状でほぼ無色の毛じ (第 1 図 B),Cタイプ: 先端部 が半球状で黄褐色の分泌物を有する毛じ (第 1 図 C), D タイプ:先端部に白色の結晶状の物質が付着した毛じ(第 1 図D)が認められた。
2. 両品種に B，C，DおよびEタイプの毛じが涊められ た.しかし，A夕イプの毛じは, プリミン保有品種のみに 認められ，フリ一品種には認められなかった。この赤褐色 の分泌物は Craven test の結果, プリミンと同定された.

3. プリミンを分泌するAタイプの毛じは，花房ではが くおよび花柄に, 葉では幼葉の裏面葉脈基部に多く発生 していた。

以上の結果から，プリムラ・オブコニカのプリミンの 有無は花房のがくおよび花柄，あるいは幼葉の裏面主脈 基部の毛じに赤褐色を呈した分泌物が有るか，否かによ って容易に判定できることがわかった。

\section{引用文献}

Bini Maleci, L., M. M. Lippi and B. Mori. 1992. Secreting trichomes in Primula obconica Hance. Caryologia 45 (2) : 123-134.

Bloch, B. and P. Karrer. 1927. Chemische und biologische Untersuchungen über die Primelidiosynkrasie. Beiblatt zur Vierteljahresschrift der naturforschenden Gesell- 
schaft in Zürich 72 (13): 1-26.

Craven, R. 1931. A sensitive colour reaction for certain quinones. J. Chem. Soc.: 1605-1606.

Heyting, J. and S. J. Toxopeus. 1987. Een snelleen eenvoudige toets op de aanwezigheid van de allergie veroorzakende stof primine in Primula obconica. Prophyta 41: $107-108$.

Heyting, J. and S. J. Toxopeus. 1989. Breeding primin-free Primula obconica. Neth. J. Agric. Sci. 37: 371-378.

肥土邦彦. 1994. 農業技術体系花斗編 8. 309-312. 農文協. 東 京.

Horn, W. 1990. Blütenfarbe und Primin. Züchtungsforshung bei Primula obconica. Deutscher Gartenbau 23: 15001501.
Horper, W. and F. J. Marner. 1996. Biosynthesis of primin and miconidin and its derivatives. Phytochemistry 41 (2) : $451-456$.

Klein, G. and O. Tröthandl. 1929. Nachweis, Verteilung und verbreitung des Primelgiftes in der Pflanze. Beiträge zur Biologie der Pflanzen 17: 211-231.

Schildknecht, H., I. Bayer and H. Schmidt. 1967. Structur des Primelgiftstoffes. Z. Naturforschung 22b: 36-41.

Storck, A. 1938. Untersuchungen zur Züchtung einer giftfreien Primel vom Obconica-Typus. II . Der Primelgehalt von Primula obconica-Kultursorten bei normalen Anzuchtbedingungen. Gartenbauwissenschaft 11: $151-158$. 